\title{
構造物のフラッタ* \\ On the Flutter of Buildings and Structures
}

中 村 泰 治**
Yasuharu NAKAMURA

\section{1.はしがき}

空気力あるいは一般に流体力の連成によって生ずる 弾性構造物の自励振動がフラッタである. 構造物とい えば籁囲は庆いが，ここでは主として地上構造物の風 によるフラッタと話を限定する*.

近年, 吊り橋, 高層ビル等の土木建築構造物の長大 化，軽量化の傾向，および熔接技術等の工法進歩に上 るない，これら構造物の可撓性の増大および構造减袈 の低下の傾向が著しい．地上構造物は航空機ほどフレ キシブルであないが，上記の傾向が進めば航空機と同 様にフラッタの発生が予想されるわけである。事実, 1940 年11月におけるアメリカ Tacoma Narrows 橋 の風による崩塤はその不幸な例であった。

地上構造物の風による応答の特徴を列挙するとつぎ のようになる.

1）はく離流であるとと．地上構造物の形驻さまざ まで非流線型であるので，まわりの流れはつねにはく 離している，すなわち，フラッタははく離流フラッタ である.

2)レイノルズ数が大きいとと，た之えば，強風時 の鋼製煙突のレイノルズ数は, 直径 $5 \mathrm{~m}$, 風速 $20 \mathrm{~m} / \mathrm{s}$ として $R=7 \times 10^{6}$, 化達する.

3）自然風の特性が影響するとと，地上風はスケー ルの大きい乱流境界層（大気境界層ともいう，厚さ

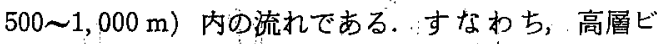
ル，長大吊り橋等の地上構造物はこの大気境界層に埋 没しているので，平均風速は棈造物の高さとともに增 大し，また，風向 風速之む，時間的空間的汇決して 一様でなく，いわ息づきがある。

以上の特徽のため，構造物のフラッタについては航 空機における非定常翼理諭8)の上うなまとまった理論 はなく，われわれの知識はきわめて不完全な模型実臨 の結果使頼っているのが現状である．設計の立場から すれば，自然風化曝された構造物の動的挙動を求める ことが最終的課題であるが，そのゴールははるか遠 く，ここでは，主として一様気流中の風洞実験より推 測される地上構造物の動的応答，とくにフラッタに焦

* 昭和 47 年 12 月 28 日原稿受理

***州大学応用力学研究所
点を絞り解説することにしたい，なお，吊り橋の耐風 性に関するすぐれた講座が数年前の本誌に揭載されて いる9．本稿ではを机を参照しつつなるべ重複しな い形で問題を取り扱ってみたい。

\section{2. 付加空気力}

弾性構造物に風が作用したときの応答を模式的にか けば第 1 四のようになる、構造物の変位にともなって 生ずる付加空気力の作用により動的循環現象が発散す れば，てれがフラッタにほかならない．以下，この付 加空気力について簡単に記す.

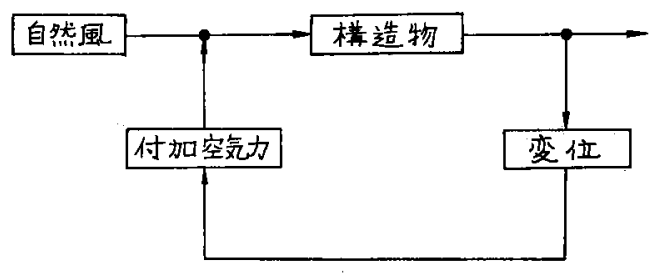

第 1 図 風による檄造物の応答

いま，二次元構造物が速度 $\mathrm{V}$ の流れに扔加机，流れ に直角方向に $y=y_{0} e^{i \omega t}$ (下向き正) の振動を行なう とき，構造物の単位幅あたりに作用する付加揚力（上 问き正）を $F(y)$ とする．力を变位と速度に同相な二 成分份分解すれば，

$$
F(y)=F_{y} y+F_{v} \dot{y}
$$

上かける. $y ， F_{y} ， F_{y}$ ををれぞれ無次元化して，

$$
\eta=\frac{y}{h}, \quad h_{a}=\frac{F_{y}}{\rho f^{2} h^{2}}, \quad k_{a}=\frac{F_{y}}{\rho f h^{2}}
$$

とかく ${ }^{10}$. こてに， $h$ は構造物の代表長， $f$, 振動数, $\rho$ は空気密度である.

空気力 $h_{a}, k_{a}$ は棈造物の形によるほか, 無次元風 速 $\bar{V}(=V / f h)$ ，振動振幅 $\eta_{0}$ おるびレイノルズ数の関 数である、いま，睤䁷一ばね系について，自由振動法 により空気力 $h_{a}, k_{a}$ を求めると，

$$
\begin{aligned}
& h_{a}=\frac{4 \pi^{2} m}{\rho h^{2}}\left(1-\frac{f_{0}^{2}}{f^{2}}\right), \\
& k_{a}=\frac{2 m}{\rho h^{2}} \delta_{a},
\end{aligned}
$$

\footnotetext{
* 航空宇宙関係では, 発射時のロケット等飛しょう体にお いて; ‘こてで述へるあのと同じ風によるフラッタを経睮 するととがあり関心をよんでいる”。
} 


$$
\delta_{a}=\delta-\delta_{0}
$$

となる. $m$ は単位幅あたりの棈造物の質量, $f_{0}$, 固有 振動数， $\delta$, 流れにおける系の対数娍衰率， $\delta_{0}$ は静止 空気中の系の刘数減衰率である.

$\delta_{a}<0$ であれば，空気力は負娍衰力となり運動を助 長する方向に働く.風による構造物の振動では，質量比 $\rho h^{2} / 2 m$ が 小さいので樭造物の振動数はほとえど変化 せず,多くの場合， $f=f_{0}$, すなわち $h_{a}=0$ としてよい.

はく離流フラッタでは，振動空気力が振動振幅 $\eta_{0}$ 飞依存する場合が多い，一般に，揚力 $F(y)$ は周期関 数であるが歪んで扣り，(1)は近似的にその基本波成 分を示しているにすぎい，また，安定なリミット・ サイクルのはか，しばしば不安定なリミット・サイク ルが現われるのあはく離流フラッタの特徴である. $\eta<\eta_{0}$ で $\delta<0, \eta \geq \eta_{0}$ で $\delta \geq 0$ であれば， $\eta_{0}$ は安定 なリミット・サイクルの振幅を示し, 逆に $\eta<\eta_{0}$ で $\delta>0, \eta \geq \eta_{0}$ で $\delta \leq 0$ であれば， $\eta_{0}$ は不安定なリミッ ト・サイクルの振幅を示す.

\section{3.うず励振}

構造物は流線型でないので，流れの中におかれると 境界層が表面ではがれ背後にカルマンうず列113が形成 される，第 2 図に KÁRMÁN によって求められたうず 配列の模式を示す．図中， $V_{W}$ はうずの流出速度であ る.うずが上下のはく離点より交互に放出される振動

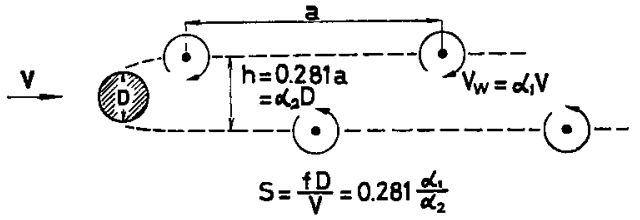

第2図 稳造物の背後に生ずるカルマンうず列

数を $f$ とすれば、ストローハル数 $S=f D / V$ は構造物 の形ならびにレイノルズ数により定まる定数である。 レイノルズ数の影響がなければ，うずの放出振動数は 風速に比例して増加する。

うず列は構造物に対して，振動数 $f$ の変動揚力なら びに変動ピッチング・モーメント,振動数 $2 f$ の変動抗 力を作用する. うず振動数 $f$ が,構造物の流れに直角 方向の固有振動数に一致する風速を $V_{c r}$ とすると, こ の風速付近で構造物は流机に直角方向の振動を励起さ れる.同様に㹉り振動あるいは流れ方向の振動す発生 し得る。とれらがうず励振にほかならない，流れ力向の 振動は，固有振動数が $2 f$ に近いとき生ずるものであ るが，普通，変動抗力は変動揚力に比して一析程度小 さく，地上構造物では流れ方向のみの励振は稀である。

棈造物断面の代表例として，第 3 図および第 4 図 に，二次元矩形断面柱および円柱のストローハル数の

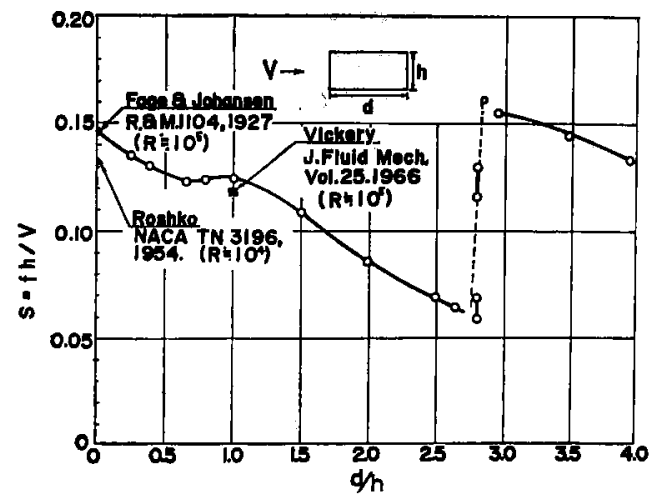

第 3 図 二次元矩形断面柱のストローハル数 $\mathrm{R}=2 \sim 6 \times 10^{4}$ (文献 12)

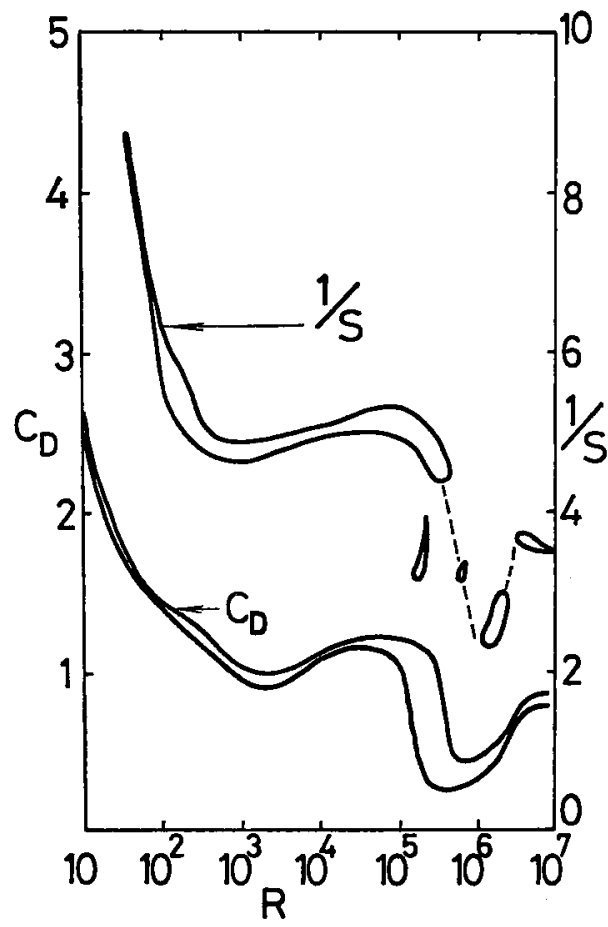

第 4 図 二次元円柱の抵抗係数とストロール数 (文献 13)

測定結果を示す ${ }^{12), 13)}$. 前述のように，ストローハル数 は，物体の形を与えると一般にレイノルズ数の関数と なるが，多くの構造物でははく噰点が鋭い角部に固定 され，レイノルズ数の影響は比較的小さいと考えられ ている. しかし，円筒状構造物では滑らかな表面で境 界層がはく離するので，ストロ一ハル数はレイノルズ 数により複雑な変化をする. とくに， $R=3 \times 10^{5}$ 付近 を境にしてはく離点における境界層が層流より乱流に 㟟移し，抵抗係数とかストローハル数は大きい变化を 受ける.

さて，PARKINSON ${ }^{14)}$ による二次元ばね支持円柱の 


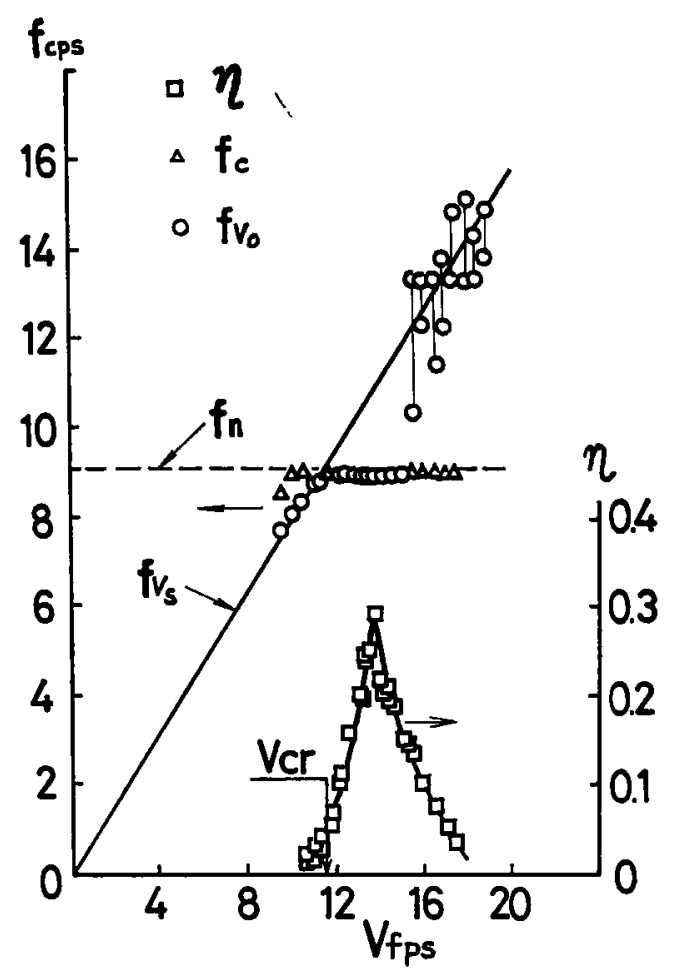

第 5 図 二次元ば权支持円柱のうず励振（文献 14）

夷験を例にとり，うず励振における構造物の忘答とそ れにともなう流れの変化について説明したい（第 5 図）励振は，限界風速 $V_{c r}\left(=f_{n} d / S\right)$ 亿きわ加近い がそれ上り低い風速において，うなりをともなう小振 幅振動ではじまる．その振動数は，円柱固有振動数 $f_{n}$ と静止円柱住対するうず振動数 $f_{v s}$ の近接した二つの 振動数よりなる.

$V=V_{c r}$ をすぎると振動振幅は急激にますが，その 最大振幅は $V=V_{\text {ar }}$ になく，この例では $V=1.3 V_{\text {or }}$ であった．さらに風速を上げると振幅は減りはじめ， $V=1.7 V_{c r}$ で励振は消えた．乙の間，円柱振動数 $f_{c}$ はほほ $f_{n}$ 亿近い值をとる. 定常振動の認められる上 記風速域以外では，円柱は $f_{c}=f_{v s}$ の微小不規則振動 (通常, $\eta 0 \sim 0.01$ 以下) を呈するのみである.

一方，円柱振動中に後流の速度変動を熱線流速計で 観察すれば，うず振動数 $f_{\mathrm{v} 0}$ は静止洔の振動数 $f_{v s}$ に必ずしす等しくないととがわかる，励振の初期，す なわち，円柱振動振幅の小さいときは $f_{v 0}=f_{v s}\left(<f_{c}\right)$ であるが，風速がまして円柱の振動振幅がますと急に $f_{v 0}=f_{c}$ となる. すなわち, 円柱の振動がうずの発生 を制御するようになる，乙の現象は，うず振動数の 円柱振動数への同期あるいは引込み現象 (frequency locking) と呼ばれている. 同期現象は最大応答を少し 越えた風速まで続く、さらに風速を上げると，まだか
なりの振幅で円柱が振動しているにあかかわらず，う ず振動数 $f_{00}$ は乫然， $f_{v s}$ にあどり (unlock)，その 後, 静止円柱の場合と変わらない変化を示す.とのよ うに，円柱振動のうず発生の制御はきわぬて非線型て ある.また，円柱振動により，スパン方向におりる速 度変動の相関か著しく增大するとともうず励振の大き な特徵の一つである ${ }^{15)}$. これらの流机の変化について は，強制振動円柱の場合により明膫に認めることがで きる(15) -17).

振動学的にいえば，カルマンうず列は一種の流体振 動子 (fluid oscillator) である.うず列の流体振動子と しての種々興味ある特性は，BISHOP'18)およびその後の 多くの研究によって示された．たとえば第6図(a)㧤 上び（b）は，加振円柱における振動揚力の測定結果 ${ }^{19}$ であるが，揚力の大きさは円柱振動振幅ならびに加振 振動数によって变化する. また, 揚力の円柱振動に対 する位相は，加振振動数をかえて行くときほぼ $180^{\circ}$ 急変する．流体振動子が “非線型”振動子であると之 の例姃として，円柱振動に対する揚・抗力㐫答のヒス テレシスや分数調波の現象を挙げるととができる ${ }^{18)}$.

うず励振をカルマンうず列による構造物の強制振

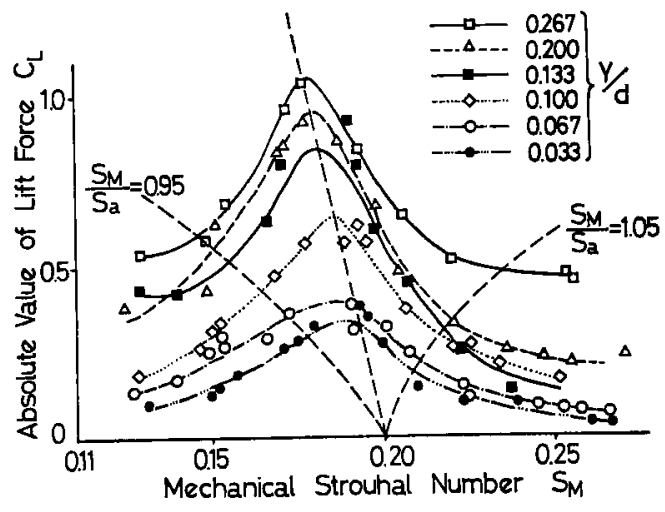

（a）揚力の大きさ

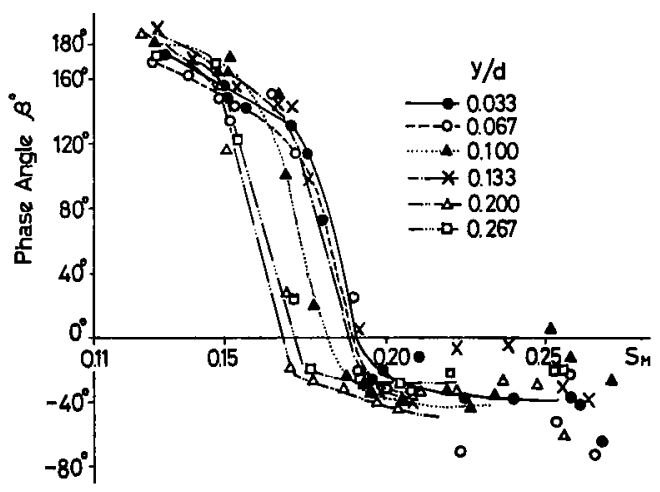

(b) 揚力の位相

第 6 図加振円枉における振動掦力（文献 19） 
動，言い換えると，一種の共振現象として説明するの は古〈からある一つの立場である201. しかし，同期現 象あるいは第 6 図(a)江示される実験事害等により， 振動源としてのうずが物体振動に制御されているとと は明らかである.したがって，うず励振をうずによる 構造物の強制振動とみるととは難しく，物体振動系に 生ずる一種の自励振動とみなす方がより適切である. ただし通常のフラッタでは，第 1 図に示すでとく振動 空気力は付加空気力のみであり，物体が静止するかぎ り振動空気力は生じ得ない，てれに対し，うず励振で は静止中であすでに振動空気力が作用することに特徵 があるので，単汇第 1 図のような 1 自由度フラッタと して取り扱うことはできない，筆者は，第 7 図のよう

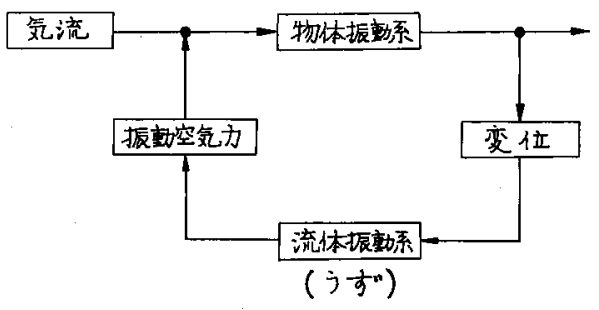

第 7 困 物体一流体振動䒺の連成自挋振動としての うず歌振（文献 21)

に，うず励振を物体－流体振動系の連成目励振動であ ると考えている21．ただし，流体振動子を厳密に定式 化することはきわめて難しく，現在，いくつかの単純 なモデルが提案されているにすぎない222. 最近, 後流 の Helmholtz 不安定に基づいた振動円柱の理論があ り注目に值する ${ }^{23)}$.

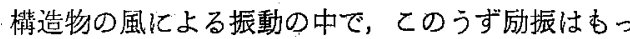
ともしばしば経験されるとてろであり，以前より知ら れていたけれども，最近の構造物の多様化，長大化の 傾向ととすにますます注目されるにいたった，その例 は枚举にいとまがないが，代表的なすのはやはり唖突 の振動であろう．最近の鋼製煙突は直径 $5 \mathrm{~m}$ ，その高 さは 150 250 m に達するすのがある. 何本かの煙哭 を束ねた集合型のものが振動を起こすととは稀である が，自立型の単独煙突の振動例は多い，第 1 表は振動 する洷突の調查例である ${ }^{24)}$ " 振動煙突のま加りの流れ
は，振動の影響のほか，レイノルズ数 $\left(R=10^{6} \sim 10^{7}\right)$, 高さ一直徍比, 先細比, 自然風の特性等が大きく影響 すると考えられ，現在なお十分な理解が得られている といい難い10),25)

鋼製煙突の円筒殻の肉厚が薄いと，うずの放出によ り半径方向の振動が生ずるととがある：とれをオーバ リング (ovaling) といっている.オーバリングは，煙 突先端部の補強により簡単に止めることができる ${ }^{26}$. 橋梁におけるうず励振も重要である，Tacoma Narrows 橋における直接の落橋原因は後述する读りフラ ッタと考えられるが，破壊以前化しばしば観測された 上下振動はうず励振之考えられる ${ }^{27}$. 最近，箱型断面 をむつ斜長橋のうず励振が注目されている28)。また， 棒梁吊材，鉄塔の補剛材に最近パイプ材が用いられる ことが多いが，乙れら部材が $4 \sim 5 \mathrm{~m} / \mathrm{s}$ の微風でうず 励振を生じ，ガセット・プレートの疲学破壊を招いた 事故例が報告されている ${ }^{29}$. な拉，風による地上構造 物では稀であるが，海洋構造物では流体力が大きいた め，流枋向のうず励振が生ずるととがあるととを付 記する

振動を防止する汒は種々のダンパーを取り付ける こ之が多いが，煙突では先端部表面に螺旋状の鉢巻 (helical strakes) を施すことがしばしば有効である ${ }^{322}$. （第 8 図）また，穴あき円筒の帽子を先端にかぶせた り (shrouded cylinder)，同じく先端に放射状のひれ (fin)を取り付けたりして同様な効果を得ることができ る.ただし，同時に抵抗が増加し転倒モーメントの增 大をむたらすので注意が必要である. 第 9 図は，斜長 橋汇扑て，断面端部の成形によりはく離を弱め，う ず励振を弱めるに成功した例である゙28．

$$
\text { 4. ギャロッピング }
$$

冬季，山中の高任送電線に氷雪が付着し断面がいび つになると，鉄塔間の送電線が風により長周期，大振 愊の振動を起てすととが珍しくない，通常，流机任直 角方向の振動が卓越する. てれがギャロッピングであ る. 以下に述べるように，ギャロッピングは構造物の ある種の静的空力特性によって生ずるもので，後者を 知れば準定常理論を利用しててれを予知することがで

第 1 表 振動煙哭の調查例（文献 24）

\begin{tabular}{|c|c|c|c|c|c|c|c|c|}
\hline Stack & $\begin{array}{r}\text { Height } \\
H(\mathrm{~m})\end{array}$ & $\begin{array}{c}\text { Diameter } \\
\text { of the top } \\
D(\mathrm{~m})\end{array}$ & $\begin{array}{l}\text { Maximum } \\
\text { measured } \\
\text { amplitude } \\
\delta(\mathrm{cm}) \\
\end{array}$ & $\begin{array}{l}\text { Measured } \\
\text { frequency } \\
f\left(\sec ^{-1}\right)\end{array}$ & $\begin{array}{l}\text { Wind velocity } \\
\text { at the top } \\
V(\mathrm{~m} / \mathrm{s})\end{array}$ & $2 \delta / D$ & $\mathrm{~S}$ & $\mathrm{R}$ \\
\hline Pittburgh & 95 & 2.6 & 76.0 & 0.55 & 7.6 & 0.58 & 0.19 & 1. $3 \times 10^{6}$ \\
\hline 姫路火力 2 期 & 76 & 3.5 & 45.0 & 1.00 & $13 \sim 18$ & 0.26 & 0.19 & 4. $3 \times 10^{6}$ \\
\hline 千桬火力 1 期 & 90 & 4. 368 & 25.0 & 0.68 & $22 \sim 25$ & 0.16 & 0.12 & $7.5 \times 10^{8}$ \\
\hline Moss Landing & 68 & 3.4 & 40.5 & 1.20 & 21.9 & 0.24 & 0.19 & $5.5 \times 10^{8}$ \\
\hline Contra Costa & 61 & 3.3 & 7.6 & 0.71 & 13.4 & 0.046 & 0.18 & $2.9 \times 10^{\circ}$ \\
\hline
\end{tabular}




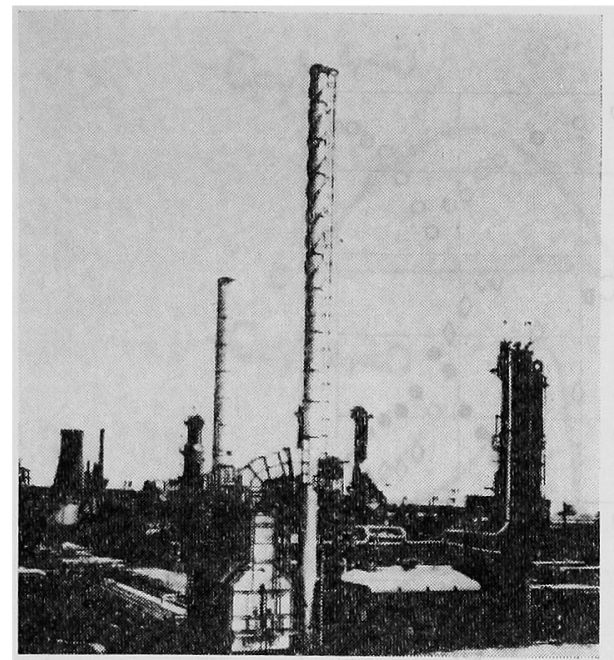

第8図 Helical strakesによる煙突のうず励振の防止例 (文献 10)

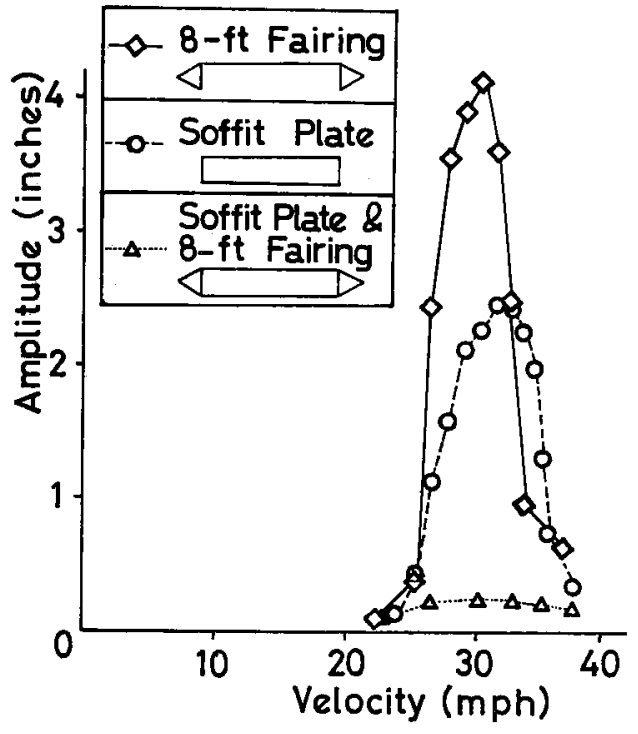

第 9 図 斜長橋におけるうず励振の防止（文献 28）

きる. 構造物のフラッタの中で, ギャロッピングは理 論的に予測可能な唯一の例であるといえる.

第 10 図のように，風速Vの一様流におかれた二次 元構造物が速度 $\dot{y}$ で流れに垂直に運動すると，構造 物には相対迎角 $\tan \alpha=\dot{y} / V$ ，相対風速 $V_{\mathrm{rel}}$ の空気力 が作用する．簡単のため，振動の各瞬間において流れ は相対迎角で与えられる定常流に等しい之仮定する と， $y$ 方向の空気力 $-F(y)$ (単位幅あたり， $F(y)$ は 上向き正）は，

$$
F(y)=\frac{1}{2} \rho V^{2} h C_{F y} \sec ^{2} \alpha
$$

で表わされる， $C_{F y}$ は揚，抗力係数より，

$C_{F y}=C_{L} \cos \alpha+C_{D} \sin \alpha$

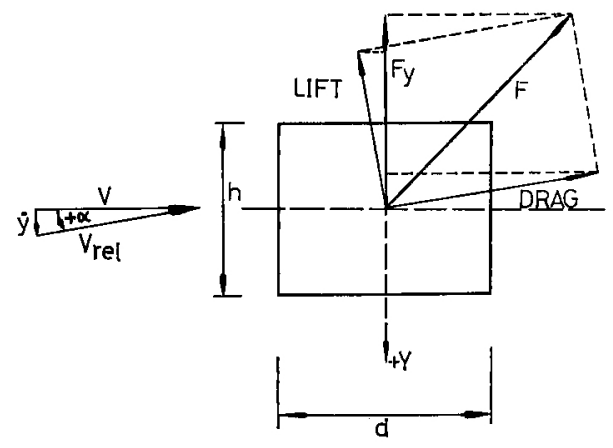

第 10 因 流れに直角に振動する構造物

と求めるととができる，微小変位を仮定すれば, $\alpha=$ $\dot{y} / V, C_{L}=d C_{L} / d \alpha \cdot \alpha$ として,

$$
\begin{aligned}
C_{F y} & =\frac{d C_{L}}{d \alpha} \alpha+C_{D} \alpha \\
& =\left(\frac{d C_{L}}{d \alpha}+C_{D}\right) \frac{\dot{y}}{V}
\end{aligned}
$$

（8）で表わされる空気力は 2 節で述べた付加空気力で あり，との場合，ダンピングとして棈造物の運動を制 御することになる.あし，

$$
\frac{d C_{L}}{d \alpha}+C_{D}<0
$$

であれば，空気力は負減衰力となり運動を助長する． こ扎がギャロッピングにほかならない（9)はDEN HARTOG の基準と呼ばれている ${ }^{33)} . d C_{L} / d \alpha+C_{D}=$ $-A_{1}$ とかき，構造物の対数減衰率を $\delta_{0}$, 質量比を $n=$ $\rho h^{2} / 2 m$ 上すれば,

$$
\bar{V}_{0}=\frac{2 \delta_{0}}{n A_{1}}
$$

で微小振動に扣ける無次元発振風速が与えられる。

第 11 㓙は正方形断面柱の 3 分力特性であるが， $\alpha=$ $0^{\circ}$ において負の揚力傾斜を有することに特徽がある. このため, $C_{F y}$ を求めると $d C_{F y} / d \alpha<0$ となり（9)を 満足する.すなわち，正方形断面柱はギャロッピング を生ずる可能性がある. 負の揚力傾斜は角部における 流れのはく離と再付着に関係している. 少し正の迎角 をつけた状態では，風上の角（図中 1 および 2) にお けるはく離流住異常が認められ，剪断層の曲率は角 1 よりも角 2 亿おける方が大きい，このため，側面の圧 力は下面の方が上面より低い．乙防が $d C_{F_{y}} / d \alpha<0$ の原因であると考えられる．迎角が大きくなると，角 3で流れの再付着を生じ, $d C_{F y} / d \alpha$ の符号が逆転す る. このような特性は正方形断面に限らず, その他の 矩形断面を含む多くの構造物断面にみられる.

さて（8)においては簡単のため線型近似を行なっ たが，一般に，静特性より(6)の $C_{F v} \sec ^{2} \alpha$ をま之め て $\tan \alpha=\dot{y} / V$ の巾級数で表せば，系の運動方程式は 


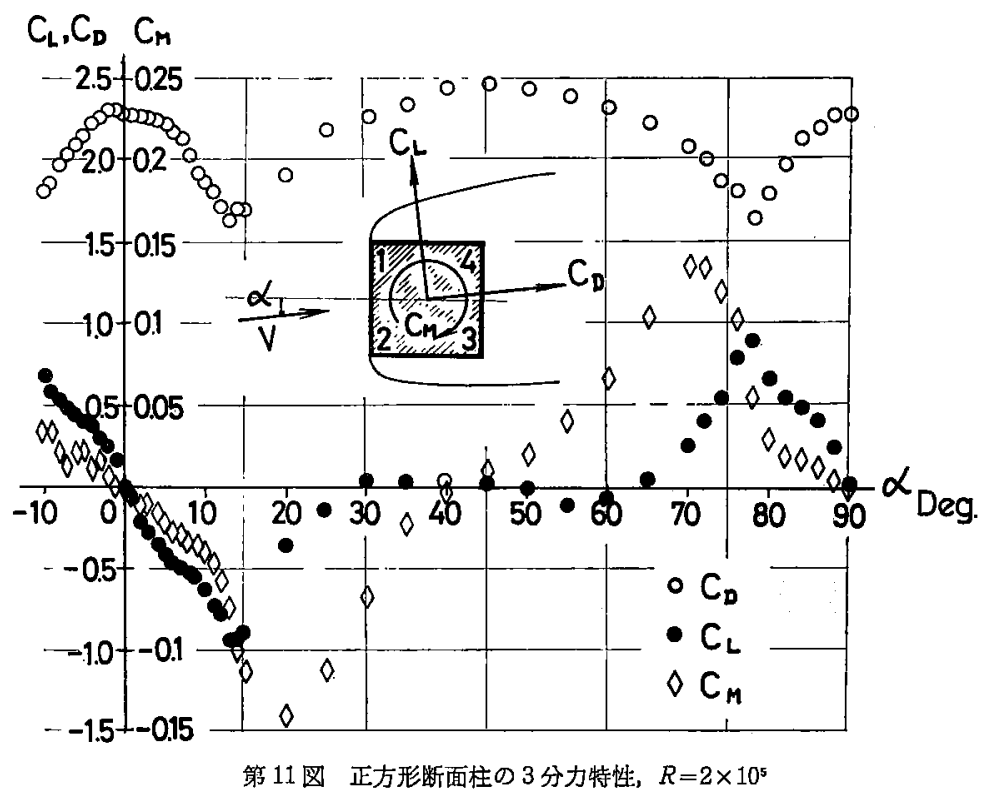

非線型ダンピングの作用する1自由度振動方程式とな り，KRYLOV-BOGOLIUBOV の方法を用いて系の安定性 あるいはリミット・サイクルの振幅等を求めるととが できる．詳緗は文献 34)，35）を参照されたい，正方 形断面柱に対する䒠駼結果を第 12 図に示すが，理論 と実験との一致はきわわてよい，ただし，第12図の䒠 験では系の構造減衰がきわめて大きく，ギャロッピン グの発生は無次元風速の大きい籁囲に限られている. 後述のように，無次元風速が低くなると準定常理諭は 破綻する.

静特性 $C_{F y}$ の形によりギャロッピングを分類すれ ば第 13 図のようになる，第 13 図(b)のように，静特 性に変曲点があれば不安定なリミット・サイクル（点

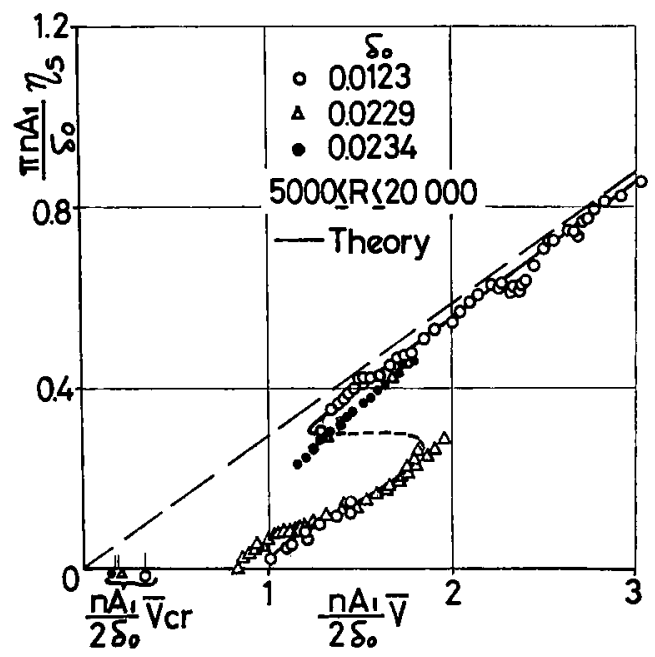

第 12 四正方形断面柱のギャロッピング（文献 34）
線）をむつ.ととで（9)で示した DEN HARTOG の 基準は，ギャロッピング発生の十分条件であるが必姴 条件ではないことをととわっておきたい，たとえば第 13 図(d)では微小振幅沈ける系は安定であるが, 突風などの外乱に上り，振動振幅が不安定なリミット ・サイクルの振幅を越えると，大振幅のギャロッピン グに移行することがあり得るわけである，注目すべき は，主流の乱れによって平均流が大きい影響をうける ことである ${ }^{35)}$.すなわち，乱れにより再付着の促進等 が行なわれ静特性 $C_{F y} \sim \alpha$ が变化する場合がある. こ

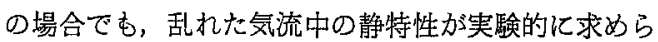
れさえすれば，滑らかな流れの場合之同程度にギャ口 ッピングを予測することができる，ただし，乱れによ り流れは必ずしむ安定化せず，滑らかな流れのとき第 13図(d)であったあのが，乱れの存在により同図(a) に移行することもあるので注意を要する.

ところで，準定常理論では，振動の各瞬間に相対迎 角に対応する定常流が実現されるととを仮定してい る. この仮定は，無次元風速の高い場合（ゆっくりし た振動）に満足されるが，風速が低くなると（早い振 動）流れの遅れが効いてくるので必ずしも満足されな くなる. との限界を理諭的に定めることは現在できな い.しかし，実験結果によ机ば，準定常理論はかなり 低い風速まで適用するととができ，その限界はむしろ うず励振の限界風速 $\bar{V}_{\text {cr }}$ との関係によって定まるよ うである ${ }^{35)}$. 一例によれば，線型準定常理論 (8)が罗 当する範囲は，ほば $\bar{V}>2 \bar{V}$ 。r であった ${ }^{36)}$. 減衰の小 さい系では，風速を上げるとまずうず励振が生じ，そ のままギャロッピングに移行することが多い10，37． 


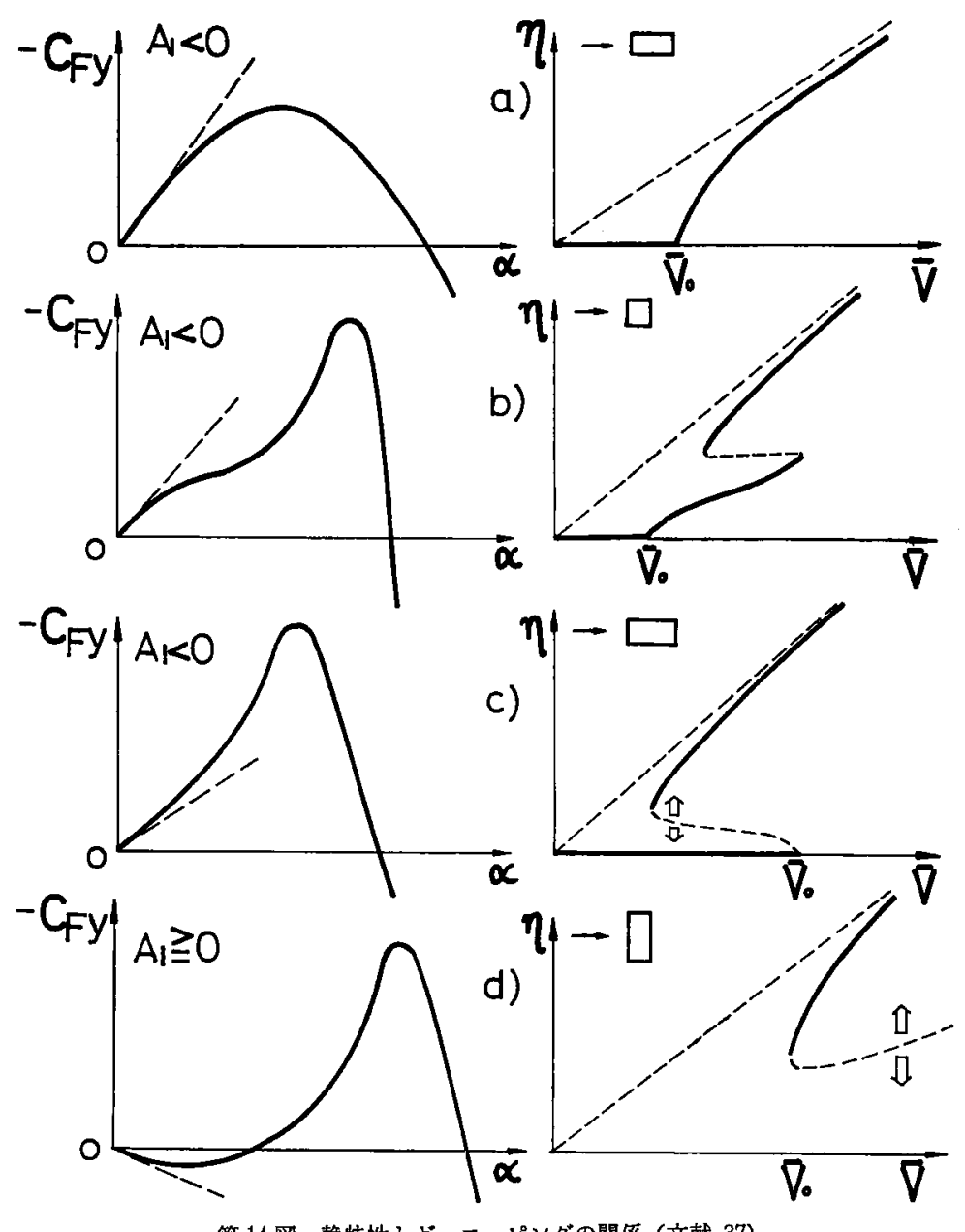

第 14 図 静特性とギャロッピングの関係（文献 37）

実例としては既に述バた送電線の振動がある゙8)。た だし，振動の発生は必ずしす水雪によらない，高压送 電線を何本加ず㨝って束ねた結果，断面形状が凹凸 になり，ギャロッピングに悩まされた例がある ${ }^{39} . と$ の場合，表面をテープで被覆し凹凸を除いて振動を止 めることができた，建物，橋梁であ，静特性が不安定 を示し発振の可能性をあつ場合があるが，未だその例 を聞かない. 将来, これら構造物の長大化の傾向がさ らにすすめば，固有振動数の低下にとあない発振風速 が設計風速に近ついてくるであろう.また，構造減衰 が大きく発振を生じていない場合でむ，負減衰空気 力の存在により系の減衰係数が低下するので注意しな ければならない，との結果，たとえば風の乱れ等によ る不規則振動の振動振幅がまし好しくない影響を与え る.そのほか，ランガー橋吊り材ではギャロッピング と考えられる事故例が散見する ${ }^{299}$.

\section{5. 据りフラッタ}

Tacoma Narrows 橋の破壊は振りフラッタによる あのと思われる. 模型実験によれば，振りフラッタは ほとんどすべての構造物に共通して発生し，しかも， 多くの場合，風速の増大亡ともに振動掁幅は急激にま しきわめて危険な現象である。それにあかかわらず， 据りフラッタについては発生の機椣も含めて多くのて とが不明である. 現在，その予知は風洞実験に頼る以 外になく今後の重要な研究課題と考えられる. 层りフ ラッタでは流れの遅れの効果が大きく、ギャロッピン グと異なり準定常理論に頼るととができない．以下， それを簡単に説明したい(0).

二次元構造物が流れの中である軸まわりに振り振動 $\theta(t)$ をしている場合を考えよう．準定常流を仮定す る之，構造物作用する空力モーメント $\bar{M}(\theta)$ は， 構造物の現在の姿勢 $\theta$, ならびにその速度 $\dot{\theta}$, 加速度

*ここでいう流れの遲れとは，主としてはく離流の対流効 果による遅れを指し，振動翼理論における流出渦 (shed vortex) による迫れと同じものである. 


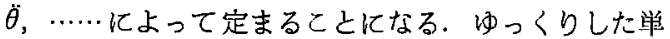
振動 $\theta=\theta_{0} e^{i \omega t}$ を対象として $\ddot{\theta}$ 以下の影響を無視す ると,

$$
\bar{M}(\theta)=\bar{M}_{\theta} \dot{\theta}+\bar{M} \dot{\theta} \dot{\theta}
$$

とかける，しかし，流れの遲れ゙を考虑するとモーメ ントは(11)で表わすととはできず，運動 $\theta$ と市に対 してある周波数特性をむつであろう. てれらをそれぞ れ， $C_{\theta} e^{i \varphi \theta}, C \theta e^{i \phi \dot{\theta}}$ とすると，非定常流におけるモ ーメント $M(\theta)$ は,

$$
\begin{aligned}
& M(\theta)=M_{\theta} \theta+M_{\dot{\theta}} \dot{\theta} \\
& =C_{\theta} e^{i \phi_{\theta} \bar{M}_{\theta} \theta+C_{\dot{\theta}} e^{i \phi} \dot{\bar{M}} \bar{\theta} \dot{\theta}}
\end{aligned}
$$

となる.ゆっくりした振動では， $C_{\theta}=C_{\dot{\theta}}=1,\left|\varphi_{\theta}\right|$, $|\varphi \dot{\theta}| \ll 1$ としてよいから, (12)の $M \dot{\theta}$ は

$$
\omega M \dot{\theta}=\omega \bar{M} \dot{\theta}+\sin \varphi_{\theta} \bar{M}_{\theta}
$$

とかける，すなわち，非定常空力ダンピングには第 1 項の準定常流的成分のほ加，第 2 項の流れの迤れによ る成分が加わるととになる. 非定常はく離流の理諭が ないので（13)の右辺第 1 項および第 2 項を独立に評 価するととはできないが，重要なととは，ゆっくりし た振動においてあ第 2 項は無視できず，むしろ場合に よっては，第 2 項が優勢とみられるととである．との 点，ギャロッピングと対照的である. ギャロッピング では，(11) に対匛して $\bar{F}(y)=\bar{F}_{y} y+\bar{F}_{\dot{y}} \dot{y}$ とかく之， $\bar{F}_{y}=0$, よって，流れの遲れは二次的効果しかるたら さず，準定常理論がよい近似を与える.

第 14 困は，種々の矩形断面柱における据りフラッ 夕の発生領域を示す37)，眓中，低速に打いて狭い局部 的発振を示すほか，振動はうず励振ではじまり，風速
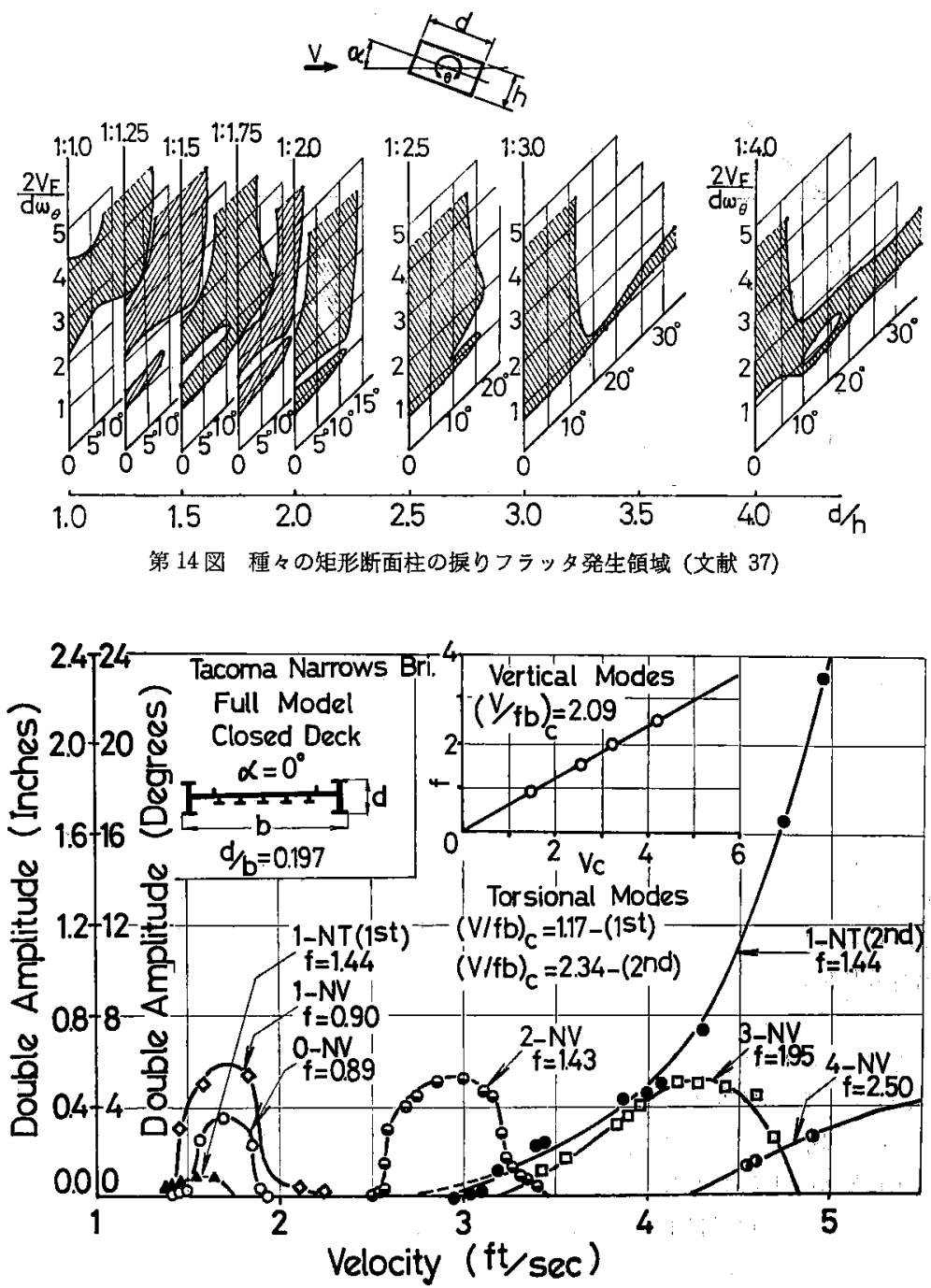

第 15 図、Tacoma Narrows 橋全橋空力弾性模型による実験結果（文献 27）困中，たとえば 1-NV は一節点上下撴動，1-NT は一節点振り振動をそれぞれ示す 
の增加之上もにそのまま据りフラッタに移行している 場合が多い.との点ギャロッピングと同様である.

第 15 図は Tacoma Narrows 橋の全橋空力弹性模 型による実験結果を示す27.。この結果は，落橋時の状 沉をきわめて忠䒠に再現したと信じられているが，捱 りモードの発散によって橋の破壊が生じたてとがわか る. 以来，ての上うな大事故はないが，多くの粠造物 が层りフラッタの潜在的危険性をもつととギャロッ ピングと全く同様である．その他， $\mathrm{H}$ 型断面をすつ橋 梁吊り材の摸りフラッタの例が見受けられるようであ $ろ^{411}$.

とてろで，上述の㨝りフラッタは、はく離点が鋭い角 に固定されている場合に生ずるフラッタであった。は く㒕点が構造物の骬らかな表面にある場合には，振動 の1サイクル中に，はく離点の移動ないしははく離の 発生と消失が生ずるので，流机の変化はさら亿複雑に なるであろう. ての種のフラッタ.は翼の失速フラッタ として知られ,最近,ヘリコプタのロータ・ブレードの 問題として研究されている. 土木建築構造物ではマイ ク口波の反射鏡, 電波望遠鏡等に生じ得る ${ }^{26}$. 第 16 図

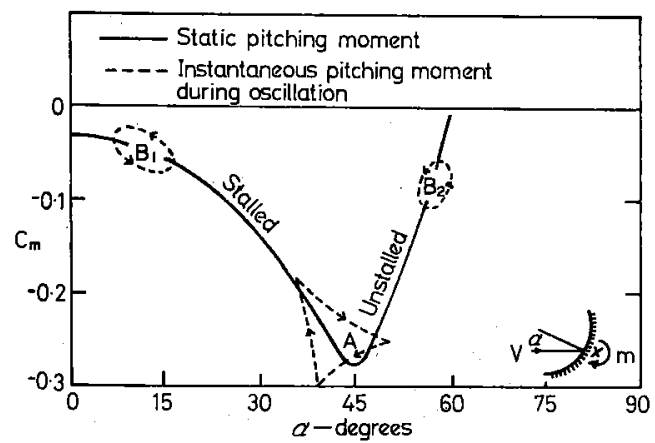

第16図 パラボラ・アンテナの空方ピッチング・ モーメント（文献 26）

はその模型実験の一例で， $\alpha=45^{\circ}$ 付近が失速角に相 当し， $\alpha>45^{\circ}$ では，背面の流れは非はく離か，た之 えはく離してす部分的はく離汇とどまっている，振動 模型のピッチング・モーメントは， $\alpha=45^{\circ}$ 付近で点 線で示す大きいヒステレシスを呈する．このモーメン 卜は明らかに負隇裹モーメントである，ちなみに，人 工衞星の追跡で有名なマンチェスター大学 Jodrell Bank 天文台の電波望遠鏡の建設に際しては，模型実 験によりてのようなフラッタの可能性が予見され，巨 大な油压ダンパーが取り付けられた.

\section{6. 連成フラッタ}

てれまで述へてきたフラッタは，いずれむ本質的に 曲げあるいは摸りの 1 自由度フラッタであった。てれ に対して，多自由度間の空気力学的連成によって生ず
る連成フラッタがある，それは，変形を拘束して純曲 げあるいは純据りにすれば振動は正減亳であるが，自 由度間の連成を許してはじぬて自励振動が生じ得ると いう意味である，航空機では䢐成フラッタが普通であ り1自由度フラッタは稀であるが，構造物のフラッタ においては逆であり，多くのフラッタは本来 1 自由度 フラッタである.

しかし，1966 年に完成した Severn 橋（イギリス） は従来のトラス補剛析形式の吊り橋と異なり，橋床断 面として翼型に似たスレンダーな箱型断面を採用する あので，建設費，維持費とも在来形式に比して格段の 低下をみたという点で注目されている22,433，Severn 橋の場合，水平汇近い風 $\left(-5<\alpha<+5^{\circ}\right)$ 飞対しては, はく離はあってあ局所的にとどまり，流れ全体は非は く離流であると考えられている．乙の上うな吊り橋の 耐風安定性は曲げ - 㨝れの連成フラッタによって支配 される，部分模型を用いた風洞実験により非定常空気 力が求められると、ストリップ理論を用いてフラッタ 限界風速を計算することができる，最近の吊り橋なら びに斜長橋の橋床断面はこの種の形式が採用される傾 向にある. この際，架設地点にちりる風の特性の調查 が肝要であって，橋床に対して迎角の大きい風が吹け ば失速状態となり，既述のはく扸流フラッタがより低 速で発生する.

\section{7. この他}

二つ以上の構造物が近接する場合は流れの干涉が生 じ，弧立構造物と異なる静的ならびに動的不安定を生 ずる.例えば，風上構造物の後流による風下構造物の バフェッティング (buffeting) およびうず励振などが 挙げられる ${ }^{43)}$. ただし，てれらはいずれるフラッタで はなく単なる強制振動と考えてよいであるう.

一般に，自然風下の構造物の応答を求めるには，架 設地点の風の特性を知る必要がある，乙こ数年来，長 大構造物の建設を一つの契機として，てのような気象 観測の資料が次第に蓄積されつつある ${ }^{12 \sim 4)}$. 設計に際 しては，まず，設計風速の適切な評価がなされるべき である ${ }^{41)}$ ．それには，架設地点における年最大風速の 統計資料，平均風速の鉛直分布，風の乱れの時閪的空 間的スケールならびに周辺地形に上る風のかたより等 を考虑する必要がある.

設計風速が定められると，設計風速内でフラッタ等 の危険な現象が生ずるか否か検討されるとととなる。 既述のように，一様気流中の風洞実跧結果よりただち に実物の応答を推定するととは難しく，実物の応答観 测は貴重な資料となる ${ }^{45), 46)}$. 近年，自然風の風洞に よるシミュレーションについていろいるな土夫が試み 
られている の構造物の空力弾性的挙動の実験も一部で行なわれつ つある51)。 また，構造物模型も野外におき自然風によ

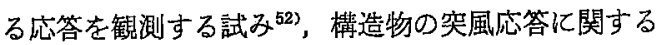
研究53354)などもある. 各種構造物断面に対する非定 常空気力の測定もわが国ではとくに盛んである ${ }^{553,56) . ~}$ これらの研究については，紙面の都合上，詳細は割爱 させていただきたい.

わ狆わ㧈の最終目標は，合理的な設計により構造物 のフラッタを防止することにある。その方法として は，1）剛性をます，2）構造減衰をます，3）構造物 の外形を流体力学的㒻地より改良する，の三つが考え られる、最初の二つは実際上なかなか実施し難く，ま ず努力すべきは 3) の方法であろう. そのいくつかの 例についてはすでに触れたが，とらわれない自由な発 想をすってすれば，なお多くの道があろうと信ずる.

\section{8. あとがき}

以上，構造物のフラッタについて概観したが，材料 の取猞選択のまずさ，笔者の思わぬ独断的見解などが 多くあることを恐れている，乙の点，御寛容いただき たい. 話が主として一様気流中の風洞実験の結果に限 られ，自然風中の構造物の挙動について述べるととが 少なかったてとすとくに拈詑びする，ての方面の知識 はまだ十分に体系的であるといえず，他日，別な専門 家による解説を希望するものである．なお，本州一四 国連絡橋の工事に関連して，実橋の $1 / 10$ スケールの 比較的低い風速で不安定を生ずるような実験橋を建設 し，実地観測と風洞実験とを同時に行なって従来のギ ヤップを埋めようとする試みがある77). その成果には 大いに期待すべきすの゙ある．最後に，引用文载は筆 者の手許にあるあのに限られ，決して網羅したあので はないてとをおてとわりしておきたい.

\section{文献}

1) Proc. Symp. Wind Effects on Buidings and Structures, NPL, Teddington, Vol. I and II, H. M. S. O., London, 1965.

2) Proc. Symp. Wind Effects on Buildings and Structures, Toronto, Vol. I and II, University of Toronto, 1967.

3) Proc. Symp. Wind Effects on Buildings and Structures, Loughborough, Loughborough University of Technology, 1968.

4) Proc. Third Int. Conf. Wind Effects on Buildings and Structures, Tokyo, Saikon-Shuppan, Co., Ltd., Tokyo, 1971.

5) Proc. Seminar on The Modern Design of Windsensitive Structures, Construction Industry Research and Information Association, London, 1971.

6) Lighthill, M.J. and Silverleaf, A. : Adiscussion on architechtural aerodynamics, Phil. Trans. Roy. Soc., Lond., A 269, 1971.

7) Proc. on MeetingGround Wind Load Problem in Relation to Launch Vehicles, NASA Langley Research Centre, 1966.

8) Bisplinghofr, R. L., Ashley, H. and Halfman, R. L. : Aeroelasticity, Addison-Wesley, Inc., Reading, Massachusetts, 1955.

9) 平井敦，伊藤学，岡内功：吊橋の耐風性について，日 本航空学会誌, 第 16 巻, 168 号, 1968.

10) Scruton, C.: On the wind-excited oscillations of stacks, towers and masts, 文献(1), Vol. II.

11) MrLne-Thomson, L. M. :Theoretical Hydrodynamics, Macmillan and Co., Ltd., London, 1968.

12）中口博, 橋本貴久裕, 武藤真理 : 矩形断面の柱の抗力 に関する一実験, 日本航空学会誌, 第 16 巻, 168 号, 1968.

13) Morkovin, M. V. : Flow around circular cylindera kaleidoscope of challenging fluid phenomena, Proc. Symp. Fully Separated Flows, A.S.M.E., 1964.

14) Ferguson, N. and Parkinson, G. V.: Surface and wake flow phenomena of the vortex-excited oscillation of a circular cylinder, Trans. A.S.M. E., J. Engrg. for Industry, Nov., 1967.

15) Torbes, G. H. : The unsteady flow and wake near oscillating cylinder, Trans. A.S. M.E., J. Basic Engrg., Sept., 1969.

16) Koopman, G.H.: The vortex wakes of vibrating cylinders at low Reynolds number, J. Fluid Mech., Vol. 28, Part 3, 1967.

17）種子田定俊, 本地弘之：振動する円柱の後流渦, 九州 大学応用力学研究所所報, 第 29 号, 1968.

18) Bishop, R.E.D. and Hassan, A. Y.: The lift and drag forces on a circular cylinder oscillating in a flowing fluid, Proc. Roy. Soc., Lond., A 277, 1963.

19) Yano, T. and Takahara, S. : Study on unsteady aerodynamic forces acting on an oscillating cylinder, 文献 (4).

20) Fung, Y.C. : Theory of Aeroelasticity; Dover Pub., Inc., New York, 1969.

21) Nakamura, Y.: Vortex excitation of a circular cylinder treated as a binary flutter, Rep. R.I. A. M., Kyushu Univ., Vol. XVII, No. 59, 1969.

22) Currie, I. G., Hartlen, R. T. and Martin, W.W. : The response of circular cylinders to vortex shedding, Proc. Symp. Flow-induced Structural Vibrations, Karlsruhe, August, 1972.

23) Shiorri, J.: Synchronization phenomenon in vortex shedding and its role in vortex induced oscillations of structures, 文献(4).

24）石崎潑雄, 川村純夫：振動測定加らみ鋏物煙突設計 上の諸問題，京大防災研究所年報，第 5 号A，1962.

25) Wootron, L. R. : The oscillations of large circular stacks in wind, Proc. Instn. Civ. Engrs., 43, 1969.

26) Wootton, L.R. and Sçuton, C.: Aerodynamic stability, 文献 (5).

27) Farquharson, F.B. et al.: Aerodynamic stability of suspension bridges with special reference to the Tacoma Narrows Bridge, Bull. Univ. Washington Engrg. Exp. Station, No. 116, 1949.

28) WARDLAW, R. L. : Some approaches for improving the aerodynamic stability of bridge road decks, 
文献(4).

29）成田信之：風による橋梁部材の振動，槚梁之基碟，第 5 巻, 9 月号, 1971.

30) Sainsburg, R.N. and King, D.: The flow induced oscillations of marine structures, Proc. Instn. Civ. Engrs., 49, 1971.

31) Wootron, L.R. et al.: Some aspects of the oscillations of full scale piles, Proc. Symp. Flowinduced Structural Vibrations, Karlsruhe, August, 1972.

32) Walshe, D.E. J. and Wootton, L. R. : Preventing wind-induced oscillations of structures of circular sections, Proc. Instn. Civ. Engrs., 47, 1970.

33) Hartog,J.P.den: Mechanical Vibrations, McGrawHill Book Co., Inc., New York, 1956.

34) Parkinson, G, V.: Aeroelestic galloping in one degree of freedom, 文献(1), Vol. II.

35) Novak, M.: Galloping oscillations of prismatic structures, J. Engrg. Mech. Div., Proc. A. S. C. E., Vol. 98, No. EM1, Feb., 1972.

36) Nakamura, Y. and Mrzota, T.: Galloping and vortex excitation of a rectangular block, Rep. R. I. A. M., Kyushu Univ., Vol. XIX, No. 64, 1972.

37) Oтsuкi, Y., W Ashizu, K. and others: Experiments on the aeroelastic instability of prismatic bars with rectangular sections, 文献(4).

38) Hogg, A.D. and EDwards, A.T.: The status of the conductor galloping problem in Canada, 文献(1), Vol. II.

39) Richards, D. J.W.: Aerodynamic properties of the Severn crossing conductor, 文献 (1), Vol. II.

40) 中村泰治, 港田武人：矩形断面柱の振りフラッタに いて，土木学会論文報告集，第 216 号，1973.

41）吉村虎蔵, 吉村健, 水田洋司：H型断面の檑梁吊材の 耐風安定に関する一実驗, 熊本大学工学部研究報告, 第22巻，第 1 号， 1973.

42) Walshe, D.E. J. and Rayner, D. V.: A further aerodynamic investigation for the proposed Severn suspension bridge, NPL/Aero/1010, 1962.

43) Walshe, D.E. J.: The use of models to predict the oscillatory behaviour of suspension bridges in wind, 文献(1), Vol. II.
44）土木学会，本州－四國連絡橋技術調査委員会：本州一 四国連絡橋技術調查報告望; 付属資料 1 一而風設訫 指釗 (1967) および同解説， 1967.

45) Okauchi, I., Ito, M. and Oguri, H.: Results of recent two measurements relevant to windinduced vibrations of bridges, 文献 (4).

46) Murota, T. and Ishizaki, H. : Deformations and vibrations of some actual structures due to wind, 文献 (4).

47) Davenport, A.G. and Isyumov, N.: The application of the boundary layer wind tunnel to the prediction of wind loading, 文苚(2), Vol. I.

48) Cermak, J.E.: Laboratory simulation of the atmospheric boundary layer, AIAA J., Vol. 9, No. 9, 1971.

49) Couninan, J.: An improved method of simulating an atmospheric boundary layer in a wind tunnel, Atmos. Environ., Vol. 3, 1969.

50) campbeli, G.S. and Standen, N.M.: Progress report II on simulation of earth's surface winds by artificially thickened wind tunnel boundary layers, National Aero. Establishment, Canada, LTR-LA-37, 1969.

51) Dayenport, A.G., Isyumov, N. and Miyata, T.: The experimental determination of the response of suspension bridges to turbulent wind, 文献 (4).

52）立川正夫：刍柱の振勳と変動風压関する自然風中の 実臥，棈造物の耐風性に関する第 2 回シンポジウム論 文集, 1972

53) Kawashima, S. and Fujimoto, N.: An investigation of the sinusoidal gust loads, 文献 (4).

54) Shiraishi, N.: An investigation on aerodynamic responses of plate-like structures in fluctuating gusts, 文献 (4).

55）鉒口展宏, 坂田弘：つり橋の耐風安定性に関する基整 研究，日本航空学会誌，第 13 巻，133 号，1965.

56）田中宏，伊藤学：充腹槛造物の自励振動におりる空気 力の特性，土木学会論文報告啭，第 168 号，1969.

57）土木学会，鋼構造委員会，本州－四國連絡橋耐風研觉 小委員会：本州一四国連絡橋・耐風関する研究，土 木学会誌, Vol. 57-8, 1972.

\section{空気力学と天文学の境界領域の話題* Topies of Cosmic Gasdynamics}

\author{
挼 井健 郎**・松田卓也** \\ Takeo Sakurai and Takuya Matsuda
}

飛行機やロケットのまわりの気体の流れを諭ずる空 気力学と，恒星や銀河を論ずる天文学は，一見何の関 係もないように思える.しかし，遠くて近きは，男女の 仲だけではない，論より証拠，手近な天文学の本を䦥

* 昭和 48 年 4 月 11 日原稿受理

** 京都大学工学部航空工学科
いて見よう．そこには、恒星が気体の塊であることが， その恒星の飛ぶ空間が気体で充たされているととが述 べられている，そして，悠久不変そのあのに見える星 空が, 実は，超新星の大爆発，銀河の腕の作る衝撃波， 星間空間を超音速で飛ぶ星のソニック・ブームなどの 空気力学的過程に彩られ，時々刻々変化する動的な空 間であるてとも述べられている，一時期空気力学者の 血を漂かせた電磁流体力学の創始者は，当時ストック 